\title{
Gumbrecht: latência na história
}

José Luís Jobim (UFF)

GUMBRECHT, Hans Ulrich. After 1945: Latency as Origin of the Present. Stanford: Stanford University Press, 2013.

Na leitura do novo livro de Hans Ulrich Gumbrecht, duas dimensões chamam a atenção: uma diz respeito à forma, outra ao conteúdo.

No que diz respeito à forma, é importante assinalar que se trata de uma obra que não segue estritamente o padrão de textos acadêmicos, com um enunciador distanciado de terceira pessoa. Em After 1945: Latency as Origin of the Present, há também um enunciador que é narrador-personagem, produzindo opiniões em primeira pessoa. De fato, no livro convivem os dois tipos de enunciador, e o leitor atento já pode perceber isso a partir do sumário: lá se podem encontrar formulações mais tradicionais, como pares opositivos (No Exit/No Entry; Bad Faith/Interrogations; Derailment / Containers) ou titulações que parecem remeter a elaborações conceituais (Forms of Latency), mas também se apresenta a voz de um narrador-personagem em primeira pessoa (Unconcealment of Latency? My Story with Time). Este narrador-personagem produz um efeito de subjetividade confessional e reflexiva. A reflexão não serve apenas para ilustrar alguma argumentação produzida, mas ganha extensão e densidade, ao dialogar intensamente com a teorização que se elabora, mesmo contra o desejo de Gumbrecht, que declara: "Não tive intenção de desenvolver, ilustrar ou aplicar nenhuma "teoria" (muito menos "método") - entretanto muito do meu trabalho com o problema existencial tirou proveito e dependeu do pensamento de muitos predecessores, colegas e estudantes."

O efeito de subjetividade confessional ganha verossimilhança não somente nas suas menções mas também nas suas omissões, como a de nomes de personagens que se relacionam com o narrador-personagem. Como exemplo do primeiro caso, podemos citar os familiares; como exemplo do segundo, o de Hans Robert Jauss (citado pela relação funcional como ex-orientador, não pelo nome).

O resultado final da mistura do texto "objetivo" com o "subjetivo" é interessante, porque há uma certa direção de sentido conduzindo o leitor a entender as conclusões a que chega o narrador-personagem na parte final do livro como relacionadas à argumentação "objetiva" anteriormente produzida.

Quanto à estruturação do conteúdo, ao elaborar uma descrição de algumas situações culturais da década de 1945-1955, procurando depreender a stimmung (o clima, a atmosfera só- 
cio-cultural) daquele período, Gumbrecht, entre outras coisas, seleciona um universo de autores e textos que ele interpreta como sendo instâncias comprobatórias da existência dos topoi por ele organizados em pares nos capítulos da obra, como títulos. Esses pares designariam uma direção de sentido disseminada amplamente. Por exemplo, em relação ao par No Exit / No Entry (sem entrada/ sem saída), Gumbrecht afirma: “O desespero de não ser capaz de sair e o desespero de não ser capaz de entrar (...) são onipresentes em textos da década seguinte ao fim da segunda guerra mundial - não somente em textos daquelas culturas cujas nações participaram nas ações militares."

Como a escolha dos autores e obras é feita em função de uma demonstração da existência de lugares-comuns, configurados nos pares que dão título a capítulos, o repertório de textos escolhidos para análise segue essa lógica, e é bem eclético quanto ao gênero e à qualidade. No caso dos textos mais próximos dos estudos literários, a seleção abrange autores mais valorizados pela tradição recente, como Becket, Camus, Faulkner, Gottfried Benn, Paul Celan, Bertolt Brecht, Boris Pasternak, Francis Ponge, Jean-Paul Sartre, Guimarães Rosa, João Cabral de Melo Neto, e autores que só são lidos por professores de literatura como dever profissional, como Giovannino Guareschi, Yuri Triponov, Luis Martín-Santos. No entanto, há também textos filosóficos, matérias de jornal, cartas. De fato, Gumbrecht não entra na questão do mérito (ou da ausência dele) no universo textual abordado, já que faz dele um uso demonstrativo, por assim dizer.

Ao tematizar a situação do pós-guerra, ele a interpreta como "global", porque envolveria uma rede de desafios, preocupações e encaminhamentos de soluções que afetariam não somente as nações mais intensamente envolvidas no conflito, mas também outras, como o Brasil. Alguns contornos daquela situação, segundo ele, ainda estariam presentes hoje, mas a percepção disso não seria a mesma do passado.

Gumbrecht desenvolve bons argumentos para sustentar que os temas, provocações e tarefas daquele período não eram percebidos então como novos ou surpreendentes, mas como problemas recorrentes, derivados de tempos anteriores. Ele aponta a emergência de um sentimento crescente de impaciência e frustração sobre a escassez de soluções à vista, e considera isso como resultado da ausência de novas respostas a antigas perguntas. Claro, nem sempre se conhece a abrangência do que pode vir a ser articulado como pergunta (ou como resposta), e o livro busca, entre outras coisas, tematizar a situação de latência, conceito chave no livro:

“Em uma situação de latência e na presença de um clandestino nós estamos certos de que algo (ou alguém) tem uma articulação material, que significa que requer espaço. Obviamente, não somos nem capazes de dizer exatamente de onde vem essa certeza nem onde o que está latente poderia precisamente estar. E 
porque não estamos familiarizados com a identidade do objeto ou pessoa latente, não temos garantia de que poderíamos reconhecer o latente se em algum momento aparecesse. Evidentemente o que está latente pode muito bem modificar-se enquanto permanece indetectável. No entanto, o mais importante é que não temos razão para acreditar - nenhuma razão sistemática, pelo menos - que aquilo que uma vez se tornou latente vai algum dia se mostrar ou tornar-se completamente esquecido."

O narrador-personagem argumenta que a vida de sua geração foi marcada pela expectativa e pela esperança de que algo "latente" viria à tona e se mostraria, permitindo aos membros dessa geração escaparem da longa sombra de um Stimmung cuja origem nunca foram capazes de identificar. Essa expectativa e esperança de um desvelamento da latência e, por consequência, de um sentimento geracional de "redenção" nunca teria sido preenchida.

Gumbrecht considera que aquilo que emergiu depois de 1945 não poderia realmente ser chamado de "latência", embora fosse possível descrever como Stimmung, isso é, tanto como uma atmosfera abrangente quanto como um clima experimentado subjetivamente: "Recordar-se de Stimmungen pode dar a certeza retrospectiva de que algo negligenciado, ignorado, e algumas vezes mesmo perdido teve um impacto decisivo na vida de um momento histórico - e frequentemente continua a ser parte do que compõe cada presente subsequente."

O uso do termo cronótopo (criado por Bakhtin para configurar o tempo em correlação com o espaço e uma weltanschauung inserida em determinada forma), para designar uma certa construção de sentido do tempo, foi uma opção interessante também, porque remete a um tempo significativo, ainda que efetivamente venha a significar coisas diferentes. E o que veio a significar, para o narrador-personagem?

Em suas próprias palavras, ele declara: "Cresci com a expectativa de que um dia alguma coisa se tornaria clara, alguma coisa que eu não sabia - que eu acreditava não saber ainda - o que era." Ao resumir, então, sua experiência com o cronótopo de sua geração, o narrador-personagem elabora sobre o seu passado e de sua geração:

"Então minha história com o tempo (e, de novo, eu assumo que não foi somente minha história individual) foi uma expectativa constante e constantemente frustrada de que algo crucial se mostrasse - e o esforço de uma vida inteira para adaptar as visões de futuro e passado a esse ciclo repetido de expectativas e frustrações."

Por outro lado, o modo de dar sentido ao tempo será, na visão do narrador, diferente para seus netos do que foi para ele, porque o futuro não será mais experimentado como um horizonte de possibilidades a partir das quais se podem fazer escolhas, 
mas como uma multiplicidade de ameaças vindo em direção do ser humano. A exaustão de recursos naturais do planeta e o aquecimento global, frutos da ação humana no passado, não são algo que pode ser deixado para trás, mas, isto sim, algo que invade o presente dos netos do narrador. Um presente cada vez mais alargado de simultaneidades, em que, inclusive por causa das tecnologias cada vez mais desenvolvidas de armazenamento de dados, nada é deixado de lado.

Com um presente que se alarga cada vez mais, surgiria a impressão de que nos encontramos em um momento de estagnação, e de que o tempo não seria mais agente de mudança, mas, se não é possível mais deixar nada para trás, também não é possível descartar completamente o cronótopo anterior: “... meus netos podem continuar a usar e reciclar os conceitos do velho cronótopo - embora ele não mais corresponda ao comportamento cotidiano deles dentro das dimensões modificadas do passado, futuro e presente."

Ponto a ser destacado, segundo o narrador, é como o novo cronótopo do presente estendido se relaciona com um período de latência na década posterior à segunda guerra mundial:

“Parece uma hipótese plausível que o período pós-guerra de latência foi uma primeira ruga no correr sem obstáculos do 'tempo histórico', isto é, uma primeira ruga no 'tempo histórico' como um cronótopo cujas três condições chave de deixar o passado para trás, atravessar um presente de mera transição e entrar no futuro como um horizonte de possibilidades tinham sido tão consideradas como garantidas por gerações anteriores que elas confundiam essa topologia específica com o 'tempo em si' ou com a 'história em si'".

Refletindo criticamente sobre a geração que passou por isso, o livro de Gumbrecht é uma contribuição marcante para uma melhor compreensão do passado e de seus efeitos no presente e na imaginação sobre o futuro. 